\title{
SEMANTIC SYNCRETISM OF CONSTRUCTIONS EXPRESSING CIRCUMSTANTIAL RELATIONS IN TATAR AND OTHER TURKIC LANGUAGES
}

\author{
Leniza Gazinurovna Khabibullina, \\ G. Ibragimov Institute of Language, Literature and Art, \\ RT Academy of Sciences, \\ 12 Karl Marx Str., Kazan, 420111, Russian Federation, \\ valievalg@mail.ru.
}

Daniya Abuzarovna Salimova, Elabuga Institute of Kazan Federal University, 89 Kazanskaya Str., Elabuga, 423604, Russian Federation, daniya.salimova@mail.ru.

\begin{abstract}
The study of circumstantial relations, reflecting the interdependence of reality phenomena, in Tatar and other Turkic languages, is mainly reduced to the analysis of individual private varieties. At the same time, the combination, the secret representation in one syntactic construction of two or more meanings, often remains out of sight of researchers and requires a multidimensional scientific description. The presented article, based on the material of Tatar and other Turkic languages, explores how the meanings of purpose and reason, condition and time are interwoven, which allows defining the nature of intermediate semantic communications.
\end{abstract}

Key words: Tatar language, Turkic languages, circumstantial relations, semantic syncretism, cause and effect, purpose, condition, time.

The study of semantic relations between syntactic formations in related Turkic languages is of scientific interest in terms of identifying similarities and differences of linguistic means used to express particular relationships and to observe the representation of one semantic concept in different languages.

The purpose of the article is to identify the semantic syncretism of constructions, denoting the existing relations in Tatar and other Turkic languages (in particular, purpose and cause-effect, condition and time). To solve this problem, we used the methods of linguistic description, transformation, and semantic analysis.

The data were obtained from works of fiction, small genres of Turkic folklore, and colloquial speech.

The research was carried out in the structural and semantic aspects and on the basis of the theory of synchronous transition (syncretism), developed by V. V. Babaytseva [Babaitseva]. The theory is based on the philosophical views of M. Foucault, J. Holton, N. da Costa, N. Vasiliev, N. Bor, L. Zadeh, etc. and logically continues the thoughts of L. V. Shcherba: along with the names of the basic concepts there are additional shades characteristic of other concepts [Druzhinina].
Syncretic constructions have a mutual combination of different types of semantic relations, with the syncretism of features in different proportions.

Circumstantial relations are characterized by a wide-semantic variation. In linguistics, their logical and semantic types are defined: space, time, cause-effect, purpose, condition, and inverse condition. As for the syncretism of the cause-effect and purpose relationships, cause is a matter that creates another phenomenon called 'effect'. In the context of time, the reason is always ahead of the effect. In purpose relationships, one situation is a potential outcome of the other. At the same time, in one of these situations, the stimulus is reported and the predicted result is presented, and in the other there is a case leading to the expected result.

"At the initial stages of the thinking development, there is a mutual combination of the meanings of cause and purpose" [Maslieva, p.26]. The ancient Greek philosopher Aristotle (384-322 BC) identified four different causes of reality, including the cause of purpose [Radugin, p. 60]. Thus, purpose is seen as a kind of cause.

According to some linguists, purpose is a concept that can be explained, and reason is inexplicable. "Purpose is explained through cause; on the other hand, when describing causal vocabulary, we 
cannot but refer to the situation of purpose" [Boguslavskaia, Levontina, p. 69].

Indeed, the concept of purpose includes the meaning of cause. In the presence of purpose relations, the reason for the subject process performance is the achievement of the expected result. Thus, the concept of purpose is directly related to the desires and aims of the subject.

The difficulty in separating purpose and causeand-effect relations in Tatar and other Turkic languages is primarily due to the use of the same means in the constructions expressing them.

In Turkic languages, the adverbial of purpose / adverbial clause of purpose and adverbial modifier of cause / causal clause can subordinate the principal part / principal clause with the help of the postposition өчен or $\partial и$. For example: tat. . Егет тә, кыз да тырышлыклары өчен уңыш бәйрәмендә бүләкләнәләр (G. Mukhametshin); Без бит монда хушлашыр өчен килдек (R. Zaidulla).

In both sentences there is the postposition өчен, which connects the subordinator and the principal part, and establishes certain semantic relations between them (тырышильклары өчен бүләкләнәләр and хушлашыр өчен килдек). In the first example, a young man and a girl are awarded for diligence, that is, the award is the result of their efforts, perseverance is the reason for the award (cause-effect relationship is expressed). The second sentence has a specific purpose of coming (came to say goodbye), the action aimed at the future, it is formally expressed (adverbial of purpose is the verb in the future tense хушлашыр), in this case, there are purpose relations between the components.

The purpose always refers to another action, which is the means of its realization in another period of time. In the presence of cause-effect relationships, they happen simultaneously, despite the fact that cause is performed before effect: a temporal sequence of events.

In the following Tatar example: (1) Жир белән Күк сугыша дип, (2) йөрәгем яргаланды (R. Haris) the subordinate clause (1) is connected with the principal clause (2) with the help of the word $\partial u n$. Between the components of the complex sentence there is a causal relationship: the heart of the lyrical hero causes tension between the Heaven and the Earth.

In these examples the subordinate clauses, which connect the principal clause by means of the word $\partial u n$ and the imperative mood verb form are final clauses because the processes, identified in the second sentence, achieve the purposes identified in the first one.

The meaning of purpose, as opposed to causeeffects, is closely related to the semantics of desire. The form of imperative mood denotes the meaning of desire. For example: azerb. Вәли јолдашы илә көрүшсүн дејо ахшам онлара кетди; tat. Балалар ач булмасын дип, сату өчен икмәк пешерә, прокатка машина алып кием тегә, бәйләү бәйли (A. Bayanov); uzb. Вақ̆т ўтмасин деб, болтни устахонада тайёрлатдим.

The ways of expressing causal relationships are the forms of the adverbial participle. With the help of the adverbial participle, additional working environment is expressed. The meaning of purpose can manifest itself through the adverbial participle form.

As can be seen from the analysis of examples, when presenting cause-effect relations the adverbial participle forms, in most cases, indicate motives for the execution of the process and emotional and mental state of the subject. For example: tat. Баласын тартып алуларыннан куркып, күкрәгенә ныграк кысты (M. Khuzin); Албуга уңайсызланып кыли-кызыл булды (N. Fattah); Хаксызлькныь күреп ярсыйм, шашам, Mатурлыкны күреп тезләнам (R. Valeev).

As we can see, these sentences express reasons, which have involuntarily led to the result. The forced result may depend on the physiological state of the person. For example: Тән өшеп-тунылn калтырана (N. Gimatdinova).

Thus, the above example expresses the state of the subject and the cause of this state.

If there is a purpose relation, the process takes place with a specific purpose, voluntarily, the specific intention of the subject is expressed. For example: tat. Әнкәй, бәлеш пешерергә ж⿻ыенып, мичкә ягып жичбәрде (R.Valeev).

In this case, lexical semantics plays a certain role in conveying the meaning of purpose. It is in the verb жысенырга (to be going to) that a sense of intention and purpose are expressed.

Purpose can be expressed by postposition белән: эм белән килү. With this postposition, the cause-effect is specified. As a rule, the reason for the action or the state of the subject is emphasized by means of the postposition белән. For example: tat. Яшьлеге бельн беркатль Равиль аларның кулларыннан товарны тартып диярлек ала (F. Yarullin); Хажсиәхмәт узе килеп керде, кызульгы белән Фатихка сугып жсибәрде (G. Galiev); Turkmen. Диймек, сен яравсызлькк билен Ростовда сакланыпсыңда. 
Thus, to separate the purpose and cause-effect relations it is important to define the semantic content of the sentence.

In the case of conditional relations, the subordinate part expresses the condition necessary in the process execution, which is expressed in the principal part. In this respect, they are close to the cause-effect relations, the components of conditional constructions can be considered the cause and effect. Unlike cause, condition is always pointing to alleged events. In other words, condition relations combine the processes that are assumed, that could be performed.

According to viewers, cause-effect and condition-effect relationships are different. According to some linguists, the semantic relationships between condition and result should be seen as causal, that is, cause-effect relations. "The fulfillment of condition automatically leads to the appearance of result, except for the cases when the will of the speaker is expressed. If the narrator knows about the objective regularity, his message returns to the listener [Tipologiia uslovnyh konstruktsii, p. 28]. In conditional constructs, condition and result are defined as possible or impossible.

In Turkic languages, conditional relations in all styles are often expressed in the form of condition, which is the main indicator of the meaning of condition. The form of this verb cannot be the predicate of the principal sentence; it is always the predicate or its part in the subordinate clause. For example: Azerb. Ииләр тамам јохланмаса, мән әл чәкән дејиләм; карач.-балк. Джылкъы бирден суу ичсе, тирмен суу азайыр (a proverb); Tat. Моң басса күңелне, Жыр белән ачарбыз (Kh. Tufan); Turkmen: Гурт агзасаң, гурт гелер (а proverb).

In Tatar and other Turkic languages, the synthetic subordinate clause of condition can be connected to the principal clause with an interrogative particle or the words $и к ә н$ and исә. For example: tat. Сүз бирергә ашыкма, бирдеңме инде карышма, ди мәкаль (M. Khasanov); karch.-balk. Джангур джауарыкь эсе, балчыкъ болур (а proverb); тат. Башың яшь икән - күп эш алма (а proverb).

Synthetic subordinate clauses of time can be connected to the principal clause with an interrogative particle: Azerb. Һава јахшылашдымы, ону евдә сахламаг олмур; karch.-balk. Декабрь айь жетдими, къыли башланды

In constructions with a verb of condition there can be the implicit meaning of cause-effect, oppositeness and inverse condition relations. Even in ancient Turkic sources, the ancient form of condition -cap/-cäp is used to refer to other types of subordinate clauses (for example, time and cause).

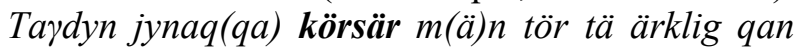
olurur. [Issledovaniia po sravnitel'noi grammatike, p. 215].

The Tatar form -ганда/-гәндә is the main indicator of expressing temporal relations, with the help of which a conditional meaning can be established between related words. For example: Әйткәндә сүзеңуча эила, дйтмәгәндә уеңчча эшла (a proverb) Газ исе сизгәндљ, 04 телефоны буенча хәбәр итегез.

It is easy to change sentences without breaking their logical meaning: Әйтсәң, сүзеңччә эшла, дйтмәсәи, уенчча эилд; Газ исе сизсәгез, 04 телефоны буенча хәбәр итегез.

The form -ганда is commonly known to express conditional meanings: Бис барбаганда кем барар?; bashk. Теләк менән дәртле йөрәк булганда, бөтәһен дә эиләргә мөмкин; kaz. Сен маган келгенде, театрга бірге баратын едік; Үзб. Рахим бизга келганда кинога борар эдик.

The analysis of these examples shows that the form -ганда allows expressing the relations, arising in the section of values of time and condition.

It should be noted that when expressing the meaning of condition, both temporal facts and repeated, constantly executed events are reported.

When comparing the form -гандa with the form $-c a$, the components lose their focus on time. For example: tat. Гаиләдә татулык булганда, эщләр унай бара $\rightarrow$ Гаиләдә татулык булса, эшләр уңай бара.

In Tatar, adverbial participles, ending with $2 a y /-2 \partial y$ that are usually used in constructions expressing time, can sometimes be used as conditional adverbial modifiers: Теләгәч сынасыннар (R. Minnullin)

Sometimes, adverbial participles ending with $n$ can have a conditional meaning. For example: Kirg. Жалгыз урунуп, турмушту көңтөрө албайсың (a proverb). It means, if you are alone, you cannot change your life. In this example, you can see the cause and effect: you cannot change your life, because you are alone.

When expressing a systematic or periodic repeated connection of two phenomena, there is a mixture of the condition and time semantics: Kum Бир зат этмеге эсине туьшсе, ол ань гъакъында йолну мастерине барып тилей; Tat. Матур парлар күрсам - куанам (A. Malikov); Китсә дә ж⿻ырлый, кайтса да жсырлый бу (S. Suleimanova). 
The abstract character of component term relations in conditional constructions is usually peculiar to paroemias and generalized expressions. For example: Alt. Am киштезе таныжар, кижи эрмектешсе таныюжар (a proverb); Karach.-balk. Джангур джауса джерге джауар (a proverb); kyrg. Жылуу сөйлөсө, жылан ийинден чыгат (a proverb); tat. Гаиль узара хөрмәт нигезенд корылса, бәхетле була! (F. Yakhin).

As can be seen from the examples, the forms of present or future tenses are used in paroemias. At the same time, the phrase itself is not connected with time, it refers to general regularity and ordinary phenomena.

The rare use of present tense forms in the past in paroemias is explained by the fact that the past, as a rule, is associated with certain phenomena, specific realities. Past tense forms have the property of individualization, but paroemias tend to generalization. Therefore, past tense forms are not often found in paroemias. For example: Kum. Яшыртгъын айтдым - билмединг, гёрюне айтдым - сюймединг (a proverb).

When predicates of compound sentences express the action without reference to some specific time or some permanent phenomenon, there is syncretism of meanings of time and condition. Most often in such constructions, time conjunctions are used, and the subordinate clause has a generalized meaning. For example: gag. Ачан бирлик йок достларда, ишлӓр гитмӓз хич орада (a proverb).

Therefore, the most common type of combining circumstantial relations in Tatar and other Turkic languages is the syncretism of cause-effect and time meanings. Both purpose and conditional relations are genetically connected to the cause-effect category.

Circumstantial relations of time serve as a background for relations of cause and effect that are directly linked to the sequence of events.

Usually, the main difference between nominally similar relations of cause-effect and purpose is the activity/passivity of the subject. Purpose refers to the future, and in order to make it a reality, it requires some deliberate, purposeful action.

Conditional relations in combination with time relations form specific condition-time constructions. This type of constructions does not specify whether these events happen simultaneously or successively, because it mainly focuses on their interdependency, rather than on their timing.

In Tatar and other Turkic languages, the main problem with identifying different circumstantial relations stems from the fact that the same nominal indicators can be used in several meanings.

As we can see from the comparative analysis of meaning and circumstantial relations in Tatar and other Turkic languages, they do not always have the necessary indicators to identify their category, the process of transition semantics often happens without any nominal devices. Thus, it is important to consider the interrelation of form and meaning. The analysis of the linguistic data shows that secret meanings and the emergence of synthesized semantics are caused by the need to present complex meaningful information.

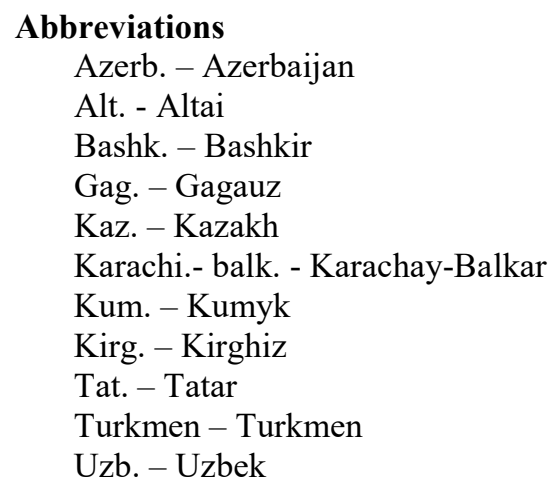

\section{References}

Babaitseva, V. V. (2000). Iavleniia perehodnosti v grammatike russkovo iazyka [The Phenomenon of Transition in the Grammar of the Russian Language]. 640 p. Moscow, Drofa. (In Russian)

Boguslavskaia, O. Yu., Levontina, I. B. (2004). Smysly 'prithina' $i$ 'tsel' $v$ estestvennom iazyke [Meanings 'Reason' and 'Purpose' in Natural Language]. Voprosy iazykoznaniia. No. 2, pp. 68-88. (In Russian)

Druzhinina, S. I. (2008). Sinkretizm v sisteme slozhnopodthinennyh predlozheniy [Syncretism in the System of Complex Sentences]. 435 p. Orel, Orel State University. (In Russian)

Issledovaniia po sravnitel'noi grammatike tiurkskih iazykov. Ch. III. Sintaksis (1961) [Studies of Comparative Grammar of Turkic Languages. Part. III. Syntax]. Pod obshh. red. N. K. Dmitrieva, N. A. Baskakova, E. I. Ubrjatovoi. 232 p. Moscow, Izd-vo AN SSSR. (In Russian)

Maslieva, O. V. (1980). Stanovlenie kategorii prithinnosti (na materiale istorii iazyka) [The Formation of the Category of Causality (based on the history of language)]. Pod red. M. G. Makarova. 105 p. Leningrad, Nauka. (In Russian)

Radugin, A. A. (2004). Filosofiia [Philosophy]. 336 p. Moscow, Tsentr. (In Russian)

Tipologiia uslovnyh konstruktsii (1998) [Typology of Conditional Constructions]. Otv. red. V. S. Hrakovskii. 583 p. St. Petersburg, Nauka. (In Russian) 


\title{
ТАТАР ҺӘМ БАШКА ТӨРКИ ТЕЛЛӘРДӘ ХӘЛ МӨНӘСӘБӘТЛӘРЕН БЕЛДЕРӘ ТОРГАН КОНСТРУКЦИЯЛӘРНЕН МӘГЬНӘ СИНКРЕТИКЛЫГЫ
}

\author{
Лениза Газинуровна Хәбибуллина, \\ ТР ФАнең Г. Ибраһимов исемендәге Тел, әдәбият һәм сәнгать институты, \\ Россия, 420111, Казан ш., Карл Маркс ур., 12 нче йорт, \\ valievalg@mail.ru. \\ Дания Әбүзәровна Сәлимова, \\ Казан федераль университетының Алабуга институты, \\ Россия, 423604, Алабуга ш., Казан ур., 89 нчы йорт, \\ daniya.salimova@mail.ru.
}

\begin{abstract}
Татар һәм башка төрки телләрдә реаль чынбарлык күренешләренең үзара бәйлелеген чагылдыручы хәл мөнәсәбәтләрен өйрәнү башлыча аларның аерым бер төрен анализлауга кайтып кала. Шул ук вакытта бер синтаксик конструкциядә ике һәм аннан да күбрәк мәгънә керешүе, синкретиклыгы еш кына тикшерүчеләр игътибарыннан читтә кала һәм фәнни тасвирлауны таләп итә. Әлеге мәкаләдә татар һәм башка төрки телләр материалында максат hәм сәбәп-нәтижә, шарт һәм вакыт мәгънәләренең бәйләнеш характеры билгеләнә, бу исә ике мәгънә арасында торган мөнәсәбәтләрнең асылын ачыкларга мөмкинлек бирә.
\end{abstract}

Төп төшенчәләр: татар теле, төрки телләр, хәл мөнәсәбәтләре, мәгънә синкретиклыгы, сәбәп-нәтижә, максат, шарт, вакыт.

\begin{abstract}
Тугандаш төрки телләрдә синтаксик берәмлекләр арасындагы мәгънәви бәйләнешләрне өйрәнү теге яки бу мөнәсәбәт белдерүдә катнаша торган тел чараларының охшаш һәм аермалы якларын ачыклау, асылында бер үк семантик төшенчә яткан категорияләрнең төрле телләрдә бирелешен күзәтү ягыннан фәнни кызыксыну тудыра.

Мәкаләнең максаты - татар һәм башка төрки телләрдә хәл мөнәсәбәтләрен (аерым алганда максат һәм сәбәп-нәтижә, шарт һәм вакыт) белдерә торган конструкцияләрнең мәгънә синкретиклыгын ачыклау. Әлеге мәсьәләне чишү өчен, лингвистик тасвирлау, трансформацион һәм семантик анализ
\end{abstract} методлары кулланылды.

Фактик материал матур әдәбият әсәрләреннән, төрки фольклорның кече жанрларыннан һәм сөйләм теленнән алынды.

Фәнни тикшеренү эше структур-семантик аспектта, аеруча В.В.Бабайцева тарафыннан системалы рәвештә эшләнгән синхрон күчеш (синкретиклык) теориясенә [Бабайцева] таянып үткәрелде. Әлеге теория М. Фуко, Дж. Холтон, Н. да Коста, Н. Васильев, Н. Бор, Л. Заде һ. б. философик карашларына нигезләнә һәм логик яктан Л.В. Щербаның төп төшенчәләр атамалары белән беррәттән башка төшенчәләргә хас булган өстәмә төсмерләр дә барлыгы хакындагы фикерләрен дәвам итә [Дружинина].

Синкретик конструкцияләрдә төрле тип мәгънә мөнәсәбәтләренең үзара керешүе күзәтелә, шул ук вакытта билгеләр синкретиклыгы, кагыйдә буларак, төрле пропорцияләрдә була.

Хәл мөнәсәбәтләренә киң семантик вариантлылык хас. Тел белемендә аларның түбәндәге логик-мәгънәви төрләре билгеләнгән: пространство, вакыт, сәбәп-нәтижә, максат, шарт һәм кире шарт. Сәбәп-нәтижә һәм максат мөнәсәбәтләренең синкретиклыгына килгәндә, сәбәп - нәтижә дип аталган башка күренешне барлыкка китерүче эш-гамәл. Вакыт ягыннан сәбәп һәрвакыт нәтижәдән алда башкарыла. Максат мөнәсәбәтләрендә исә бер ситуация икенчесенең потенциаль нәтижәсе буларак күзаллана. Шул ук вакытта бу ситуацияләрнең берсендә стимул турында хәбәр ителә һәм фараз ителүче нәтижә белдерелә, ә икенчесендә - көтелгән нәтижәгә китерүче эш-гамәл атала.

«Фикерләү үсешенең башлангыч этапларында сәбәп һәм максат мәгънәләренең үзара керешүе күзәтелә» [Маслиева, б. 26]. Борынгы грек философы Аристотель (б. э. к. 384-322 еллар) чынбарлыкның дүрт төрле 
сәбәбен, шул исәптән максат сәбәбен аерып күрсәтә [Радугин, б. 60]. Шулай итеп, максат сәбәпнең бер төре буларак карала.

Кайбер телче-галимнәр фикеренчә, максат аңлатып була торган, ә сәбәп - аңлатып булмый торган төшенчә. «Максат сәбәп аркылы аңлатыла, әмма, икенче яктан караганда, сәбәп лексикасын тасвирлаган вакытта, без максат итү ситуациясенә мөрәжәгать итми кала алмыйбыз» [Богуславская, Левонтина, б. 69].

Чыннан да, максат төшенчәсенә сәбәп мәгънәсе дә керә. Максат мөнәсәбәте булганда, субъектның процессларны башкару сәбәбе көтелгән нәтижәгә ирешү. Шулай итеп, максат төшенчәсе субъектның теләк-омтылышлары белән турыдан-туры бәйләнгән.

Татар һәм башка төрки телләрдә максат һәм сәбәп-нәтижә мөнәсәбәтләрен аерудагы кыенлык беренче чиратта аларны белдерүче конструкцияләрдә бер үк бәйләүче чаралар куллану белән бәйле.

Төрки телләрдә максат хәле/иярчен максат жөмлә, сәбәп хәле/иярчен сәбәп жөмлә кебек үк, баш кисәккә/баш жөмләгә өчен бәйлеге, дип сүзе ярдәмендә иярә ала. Мәсәлән: тат. Егет тә, кыз да тырышльклары өчен уныши байрәмендә бүләкләнәләр (Г. Мөхәммәтшин); Без бит монда хушлашыр өчен килдек (Р. Зәйдулла).

Ике жөмләдә дә иярчен һәм баш компонентларны үзара бәйләүче һәм алар арасында билгеле бер мәгьнә мөнәсәбәтләре урнаштыручы өчен бәйлеге бар (тьрышлылклары өчен бүләкләнәләр һәм хушлашыр өчен килдек). Беренче мисалда егет белән кызны тырышлыклары өчен бүләклиләр, ягъни бүләкләнү - аларның тырышлыгы нәтижәсе, тырышлык - бүләкләнү сәбәбе (сәбәп-нәтижә мөнәсәбәте белдерелә). Икенче жөмләдә килүнең конкрет максаты атала (хушлашыр өчен килдек), гамәл киләчәккә юнәлдерелгән, бу хәтта формаль яктан белдерелгән (максат хәле - киләчәк заман формалы фигыль: хушлашыр), бу очракта компонентлар арасында максат мөнәсәбәте урнаша.

Максат һәрвакыт аны тормышка ашыру өчен чара булучы эш-хәлгә карата башка вакыт яссылыгына карый. Сәбәп-нәтижә мөнәсәбәте булганда, сәбәп нәтижәдән алда үтәлүгә, ягъни вакыйгаларның вакыт ягыннан эзлеклелегенә карамастан, алар бер заман яссылыгында ята.

Тат. (1) Жир белән Күк сугыша дип, (2) йөрәгем яргаланды (Р. Харис) мисалында иярчен жөмлә (1) баш жөмлә (2) белән дип сүзе ярдәмендә бәйләнгән. Кушма жөмлә компонентлары арасында сәбәп-нәтижә мөнәсәбәте урнаша: лирик геройның йөрәге яргалануның сәбәбе - Жир белән Күк сугышуы.

Түбәндәге мисалларда баш жөмләгә дип сүзе һәм хәбәрнең боеру наклонениесе формасы ярдәмендә ияргән иярчен жөмләләр максат жөмләләр, чөнки икенче хәбәрлек Үзәкләрдә аталган процесслар, беренчеләрендә әйтелгән максатларга ирешү өчен, махсус башкарыла.

Максат мәгънәсе, сәбәп-нәтижәдән аермалы буларак, теләк семантикасы белән тыгыз бәйләнгән. Боеру наклонениесе формасы теләк мәгънәсен белдерә. Мәсәлән: әзерб. Вәли јолдашы илә көрүшсүн дејо ахшам онлара кетди; тат. Балалар ач булмасын дип, сату өчен икмәк пемерә, прокатка машина альп кием тега, бдйләү бәйли (Ә. Баянов); үзб. Вақы утммасин деб, болтни устахонада тайёрлатдим.

Хәл фигыль формалары да сәбәп-нәтижә мөнәсәбәтен белдерүнең бер чарасы булып торалар. Хәл фигыль ярдәмендә өстәмә эшхәлдә булган сәбәп белдерелә. Максат мәгънәсе дә хәл фигыль формалары аша күрсәтелә ала.

Мисалларны анализлаудан күренгәнчә, сәбәп-нәтижәне белдергәндә, хәл фигыль формалары күпчелек очракта теге яки бу процессның үтәлү мотивларына, эш-гамәл башкаручының эмоциональ-психик халәте, хискичерешләренә ишарәли. Мәсәлән: тат. Баласын тартып алуларыннан куркып, күкрдгенә ныграк кысты (М. Хужин); Албуга унайсызланып кылп-кызыл булды (Н. Фәттах); Хаксызльккны күреп ярсыйм, шамам, Матурлькны күреп тезланам (Р. Вәлиев).

Күргәнебезчә, әлеге жөмләләрдә ихтыярсыз нәтижәгә китергән сәбәпләр белдерелә. Ихтыярсыз нәтижә кешенең физиологик халәтенә бәйле була ала. Мәсәлән: Тән өшептуңып калтырана (Н. Гыйматдинова).

Шулай итеп, югарыда каралган мисалларда субъектның хәл-торышы һәм әлеге халәтнең сәбәбе белдерелә.

Максат мөнәсәбәте булганда, процесс билгеле бер максат белән, ихтыяри башкарыла, субъектның конкрет нияте чагыла. Мәсәлән: тат. Әнкәй, бәлеш пешерергә ж⿻ыенып, мичкә ягып жсибарде (Р. Вәлиев).

Әлеге очракта максат мәгънәсен белдерүдә билгеле бер рольне лексик семантика башкара. 
Жьенырга фигылендә үк ният, максат мәгънәләре бар.

Максат мәгънәсе белән бәйлеге ярдәмендә белдерелә ала: эи белән килү. Шушы бәйлек белән сәбәп-нәтижә дә күрсәтелә. Кагыйдә буларак, белән бәйлеге ярдәмендә процессның яки субъектның халәтенең сәбәбе буларак аңа хас сыйфат ассызыклана. Мәсәлән: тат. Яшьлеге белән беркатль Равилә аларның кулларыннан товарны тартып диярлек ала (Ф. Яруллин); Хажсиәхмәт Үзе килеп керде, кызульгы белән Фатихка сугып ж⿻ибдрде (Г. Галиев); төрекм. Диймек, сен яравсызлькк билен Ростовда сакланыпсыцда.

Шулай итеп, максат һәм сәбәп-нәтижә мөнәсәбәтләрен аеру өчен, жөмләнең мәгънәви эчтәлегенә мөрәжәгать итү мөһим.

Шарт мөнәсәбәтләре вакытында иярчен кисәк баш кисәктә белдерелгән процессның үтәлеше өчен кирәк булган шартны белдерә. Бу яктан алар сәбәп-нәтижә мөнәсәбәтләренә якын, шарт конструкциясенең компонентлары нигез һәм нәтижә буларак карала ала. Сәбәптән аермалы буларак, шарт һәрвакыт фараз ителгән вакыйгаларга күрсәтә. Икенче төрле әйткәндә, шарт мөнәсәбәтләре фаразланган, үтәлүе мөмкин булган процессларны берләштерә.

Сәбәп-нәтижә һәм шарт-нәтижә мөнәсәбәтләренә карата телчеләрнең фикерләре бердәй түгел. Кайбер лингвистлар әйтүенчә, шарт һәм нәтижә арасындагы семантик бәйләнешне каузаль, ягъни сәбәп-нәтижә бәйләнеше дип санарга кирәк. «Шартның үтәлүе, сөйләүченең ихтыярыннан тыш, автоматик рәвештә нәтижәнең барлыкка килүенә китерә. Сөйләүченең роле, объектив закончалык булуны белеп, аның турында тыңлаучыга хәбәр итүгә кайтып кала» [Типология условных конструкций, б. 28]. Шарт конструкцияләрендә шарт һәм нәтижә мөмкин яки мөмкин түгел буларак билгеләнә.

Төрки телләрдә шарт мөнәсәбәтләре барлык стильләрдә дә шарт мәгънәсенең төп күрсәткече булган шарт фигыль формасы белән аеруча еш белдерелә. Әлеге фигыль формасы баш жөмләнең хәбәре була алмый, һәрвакыт иярчен жөмлә хәбәре составында була. Мәсәлән: әзерб. Ииләр тамам јохланмаса, мән әл чәкән дејиләм; карач.-балк. Джылкъы бирден суу ичсе, тирмен суу азайыр (Мәкаль); тат. Моң басса күңелне, Жыр белән ачарбыз (Х. Туфан); төрекм. Гурт агзасан, гурт гелер (Мәкаль).

Татар һәм башка төрки телләрдә синтетик иярчен шарт жөмлә баш жөмләгә сорау кисәкчәсе, икән, исә сүзләре ярдәмендә иярә ала. Мәсәлән: тат. Сүз бирергә ашыкма, бирденме инде - карыимма, ди мәкаль (М. Хәсәнов); карач.-балк. Джангур джауарыкъ эсе, балчькь болур (Мәкаль); тат. Башың ящь икән - күп эи алма (Мәкаль).

Синтетик иярчен вакыт жөмлә дә баш жөмләгә сорау кисәкчәсе ярдәмендә иярә ала: әзерб. Һава јахшылашдылмы, ону евдә сахламаг олмур; карач.-балк. Декабрь айь жетдими, къьли башландыл.

Шарт фигыль формалы конструкцияләрдә имплицит рәвештә сәбәп-нәтижә, каршы кую hәм кире шарт мәгънәләре була ала. Борынгы төрки чыганакларда ук борынгы шарт формасы -cap/-cäp башка төр иярчен жөмләләрне (мәсәлән, вакыт, сәбәп) белдеру өчен

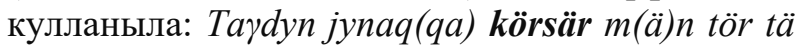
ärklig qan olurur. 'Мин өскә карагач, алгы урында Эрклигхан утыруын күрдем' [Исследования по сравнительной грамматике тюркских языков, б. 215].

Татар телендә -ганда/-гәндә формасы вакыт мөнәсәбәтләрен белдерүнең төп күрсәткече булуга карамастан, аның ярдәмендә бәйләнгән сүзләр арасында шарт мәгънәсе дә урнаша ала. Мәсәлән: Әйткәндә сүзенучә эила, дйтмәгәндә уенуча эилә (Мәкаль); Газ исе сизгәндә, 04 телефоны буенча хәбар итегез.

Жөмләләрне, логик мәгънәне бозмыйча, бик жиңел үзгәртеп була: Әйтсән, сүзенчә эилә, дйтмәсән, уенуча эилә; Газ исе сизсәгез, 04 телефоны буенча хәбәр итегез.

-Ганда формасының шарт мәгънәсен алуны гомумтөрки күренеш дияргә була: алт. Бис барбаганда кем барар?; башк. Теләк менән дәртле йөрәк булганда, бөтәһен дә эиләргә мөмкин; каз. Сен маган келгенде, театрга бірге баратын едік; Үзб. Рахуим бизга келганда кинога борар эдик.

Мисалларны анализлаудан күренгәнчә, ганда формасы вакыт һәм шарт мәгънәләре киселешендә барлыкка килүче мөнәсәбәтләрне белдерергә ярдәм итә.

Шуны да искәртергә кирәк: шарт мәгънәсе белдерелгәндә, бер генә вакыт факты түгел, ә кабатланучы, Һәрвакыт башкарылучы вакыйгалар турында хәбәр ителә.

-Ганда формасын -са формасына алыштырганда, компонентлар арасындагы вакытка юнәлгәнлек югала. Мәсәлән: тат. Гаиләдә татулькк булганда, эиләр уцуай бара $\rightarrow$ Гаиләдә татульлк булса, эиләр унъай бара. 
Татар телендә гадәттә вакыт мәгънәсен белдерүче конструкцияләрдә кулланылучы гач/-гәч формалы хәл фигыль сирәк очракларда шарт мөнәсәбәтен белдерә: Теләгәч сынасыннар (Р. Миңнуллин).

Кайвакыт - $n$ формалы хәл фигыльле конструкцияләрдә дә шарт мәгьнәсе күзәтелә. Мәсәлән: кырг. Жалгыз урунуп, турмушту көңтөөрө албайсың (Мәкаль). Ягъни ялгыз булсаң, тормышны үзгәртә алмыйсың. Әлеге мисалда шулай ук сәбәп-нәтижә мәгънәсе дә сизелә: тормышны үзгәртә алмыйсың, чөнки син ялгыз.

Ике күренешнең даими яки периодик рәвештә кабатлана торган бәйләнеше белдерелгәндә, шарт һәм вакыт семантикасының үзара керешүе күзәтелә: ком. Бир зат этмеге эсине тувшсе, ол аны гъакъында йолну мастерине барып тилей; тат. Матур парлар күрсәм - куанам (Ә. Маликов); Китсл дә ж⿻ырлый, кайтса да ж⿻ырлыий бу (С. Сөләйманова).

Шарт конструкциясе компонентлары мөнәсәбәтләренең вакытка карата абстракт характеры, гадәттә, паремияләр һәм гомумиләштерелгән әйтелмәләргә хас. Мәсәлән: алт. Am киштезе таньюсар, кижи эрмектешсе таныюсар (Мәкаль); карач.-балк. Джангур джауса джерге джауар (Мәкаль); кырг. Жылуу сөйлөсө, жылан ийинден чыгат (Мәкаль); тат. Гаилә узара хөрмәт нигезенә корылса, бәхетле була! (Ф. Яхин).

Мисаллардан күренгәнчә, паремияләрдә хәзерге яки киләчәк заман формалары кулланыла. Шул ук вакытта фраза үзе вакытка бәйле түгел, гомуми закончалыкка һәм гадәти күренешләргә ишарәли.

Паремияләрдә үткән заман формаларының бик сирәк кулланылуын үткән заманның, кагыйдә буларак, билгеле бер күренешләр, конкрет чынбарлык белән бәйләнгәнлеге белән аңлатырга була. Үткән заман формалары индивидуальләштеру үзенчәлегенә ия, ә паремияләргә гомумиләштерү хас. Шуңа күрә дә паремияләрдә үткән заман формалары еш очрамый. Мәсәлән: ком. Яшыртгъын айтдым билмединг, гёрюне айтдым - сюймединг (Мәкаль).

Кушма жөмләнең хәбәрләре билгеле бер вакытка мөнәсәбәтсез эш-хәлне яки даими күренешне белдергәндә, вакыт һәм шарт мәгънәләренең синкретиклыгы күзәтелә. Мондый конструкцияләрдә еш кына вакыт белдерүче теркәгечләр кулланыла, иярчен жөмлә гомумиләшкән мәгънәгә ия була. Мәсәлән: гаг. Ачан бирлик йок достларда, иилӓр гитмӓз хич орада (Мәкаль).

Шулай итеп, татар һәм башка төрки телләрдә хәл мөнәсәбәтләренең үзара керешү төрләре арасында иң киң таралганы булып сәбәп-нәтижә һәм вакыт мәгънәләре синкретиклыгы тора. Максат мөнәсәбәтләре дә, шарт мөнәсәбәтләре дә генетик яктан сәбәпнәтижә категориясе белән бәйләнгән.

Вакыт мөнәсәбәтләре турыдан-туры вакыйгалар эзлеклелегенә бәйле булган сәбәпнәтижә мөнәсәбәтләре өчен фон ролен башкара.

Еш кына формаль яктан аерылмаган сәбәпнәтижә һәм максат мөнәсәбәтләренең төп аерымлыгы - субъектның активлыгы/пассивлыгында. Максат киләчәккә юнәлдерелә, аның тормышка ашырылуы нинди дә булса аңлы, максатчан эшчәнлек таләп итә.

Шарт мөнәсәбәтләре, вакыт мөнәсәбәтләре белән керешеп, шарт һәм вакыт мәгьнәләре арасында торучы үзенчәлекле конструкция барлыкка китерә. Мондый төр конструкцияләргә вакыйгаларның бер үк вакытта яки эзлекле башкарылу мәгънәсен төгәл белдермәү хас, чөнки бу очракта төп мәгънәви нагрузка процессларның вакытка мөнәсәбәтенә түгел, ә бер-берсенә бәйлелегенә төшә.

Татар һәм башка төрки телләрдә төрле мәгънә мөнәсәбәтләрен аерудагы кыенлыклар беренче чиратта бер үк формаль күрсәткечләрнең (бәйләүче чараларның) берничә мәгънә белдерүдә кулланылуы белән бәйле.

Мәгънәви бәйләнешләрне чагыштырма планда тикшерүдән күренгәнчә, татар һәм башка төрки телләрдә теге яки бу конструкцияләрне билгеле бер мөнәсәбәтләргә кертеп карарга мөмкинлек бирүче махсус күрсәткечләр һәрвакыт булмый, бер семантикадан икенчесенә күчү процессы еш кына формаль чаралар ярдәмендә структур яктан күрсәтелми, синтаксик берәмлекләрнең структур-семантик төзелешен өйрәнгәндә, форма һәм эчтәлекнең үзара бәйләнешен исәптә тотарга кирәк. Тел материалын анализлаудан күренгәнчә, синкретик мәгънәләр, синтезланган семантика барлыкка килү катлаулы эчтәлекле информация тапшыру ихтыяжы белән билгеләнә.

\section{Кыскартылмалар}

әзерб. - әзербайжан

алт. - алтай 
башк. - башкорт

гаг. - гагауз

каз. - казах

карач.-балк. - карачай-балкар

ком. - комык

кырг. - кыргыз

тат. - татар

төрекм. - төрекмән

үзб. - үзбәк

\section{Әдәбият}

Бабайцева В. В. Явления переходности в грамматике русского языка. М.: Дрофа, 2000. 640 с.

Богуславская О. Ю., Левонтина И. Б. Смыслы 'причина' и 'цель' в естественном языке // Вопросы языкознания. 2004. № 2. С. 68-88.
Дружинина С. И. Синкретизм в системе сложноподчиненных предложений. Орел: изд-во Орел ГАУ, 2008. 435 с.

Исследования по сравнительной грамматике тюркских языков. Ч. III. Синтаксис / под общ. ред. Н. К. Дмитриева, Н. А. Баскакова, Е. И. Убрятовой. М.: изд-во АН СССР, 1961. 232 с.

Маслиева O. В. Становление категории причинности (на материале истории языка) / под ред. М. Г. Макарова. Л.: Наука, 1980. 105 с. $336 \mathrm{c}$.

Радугин А. А. Философия. М.: Центр, 2004.

Типология условных конструкций / отв. ред. В. С. Храковский. СПб.: Наука, 1998. 583 с.

\title{
СМЫСЛОВОЙ СИНКРЕТИЗМ КОНСТРУКЦИЙ, ВЫРАЖАЮЩИХ ОБСТОЯТЕЛЬСТВЕННЫЕ ОТНОШЕНИЯ, В ТАТАРСКОМ И ДРУГИХ ТЮРКСКИХ ЯЗЫКАХ
}

\author{
Лениза Газинуровна Хабибуллина, \\ Институт языка, литературы и искусства им. Г. Ибрагимова Академии наук РТ, \\ Россия, 420111, г. Казань, ул. Карла Маркса, д. 12, \\ valievalg@mail.ru. \\ Дания Абузаровна Салимова, \\ Елабужский институт Казанского федерального университета, \\ Россия, 423604, г. Елабуга, ул. Казанская, д. 89, \\ daniya.salimova@mail.ru.
}

\begin{abstract}
Исследование обстоятельственных отношений, отражающих взаимообусловленность явлений реальной действительности, в татарском и других тюркских языках в основном сводится к анализу отдельных частных их разновидностей. При этом совмещение, синкретичное представление в одной синтаксической конструкции двух и более значений часто остается вне поля зрения исследователей и требует многоаспектного научного описания. В представленной статье на материале татарского и других тюркских языков установлен характер переплетения значений цели и причины, условия и времени, что позволило определить природу промежуточных смысловых связей.
\end{abstract}

Ключевые слова: татарский язык, тюркские языки, обстоятельственные отношения, смысловой синкретизм, причина и следствие, цель, условие, время. 